\title{
Avusturya'da Yaşayan Türkiye Cumhuriyeti Vatandaşı Seçmenlerin Siyasal Davranışları Üzerine Bir Araştırma ${ }^{*}$
}

\author{
Ramazan ASLAN \\ Dr. Öğr. Üyesi, Adıyaman Üniversitesi, \\ İktisadi ve İdari Bilimler Fakültesi, İşletme Bölümü \\ ramazanaslan@adiyaman.edu.tr \\ Orcid ID: https://orcid.org/0000-0002-1427-8543 \\ Yusuf KILIÇ \\ Doktora Öğrencisi, Hasan Kalyoncu Üniversitesi, \\ İşletme Bölümü \\ yusufkilic_02@yahoo.com \\ Orcid ID: https://orcid.org/0000-0002-9802-0979
}

\begin{abstract}
Öz
Siyaset ve pazarlama kavramlarının ve uygulamalarının birlikte ele alınmasıyla siyasal pazarlama kavramı ortaya çıkmıştır. Siyasal pazarlama alanında yapılan yenilikler ve gelişmeler, siyasal başarı açısından dikkatlice takip edilmektedir. Seçmenlerin kararlarını ve davranışlarını etkileyen birçok faktör bulunmaktadır. Bu bağlamda, siyasal pazarlama kavramını merkeze alan bu çalışmanın amacı, demografik faktörlerin Avusturya'da yaşayan Türkiye Cumhuriyeti vatandaşı olan seçmenlerin siyasal davranışları üzerindeki etkilerini incelemek olarak belirlenmiştir. $\mathrm{Bu}$ amaç doğrultusunda, çalışma iki bölüme ayrılmıștır. Birinci bölümde, siyasal pazarlama alanındaki temel kavramların tanımlamaları, ikinci bölümde ise, Avusturya'da yaşayan Türkiye Cumhuriyeti vatandaşlarının siyasal davranışlarının demografik faktörler açısından analizi ve sonuçları verilmiştir. Elde edilen bulguların değerlendirilmesi ve bundan sonraki çalışmalara yönelik öneriler ile çalışma tamamlanmıştır. Sonuç olarak bu çalışmanın, ulusal ve uluslararası literatüre katkı sağlaması beklenmektedir. Ayrıca, siyasi partilerin yurtdışında yaşayan seçmenlere yönelik gelecekte yürütecekleri siyasal kampanya faaliyetlerine katkı sağlayacağı düşünülmektedir.
\end{abstract}

\footnotetext{
${ }^{1}$ Makale Geliş/Kabul Tarihi: 21.04.2021/22.12.2021

* Bu makale "Avusturya'da Yaşayan Türkiye Cumhuriyeti Vatandaşı Seçmenlerin Siyasal Davranışları Üzerine Bir Araştırma” başlıklı yüksek lisans tezinden üretilmiştir.

Künye Bilgisi: Aslan, R. ve Kılıç, Y. (2021). Avusturya’da yaşayan Türkiye Cumhuriyeti vatandaşı seçmenlerin siyasal davranışları üzerine bir araştırma. Kahramanmaraş Sütçü Imam Üniversitesi Sosyal Bilimler Dergisi, 18 (3), 1835-1854. DOI: 10.33437/ksusbd.925194.
} 
Anahtar Kelimeler: Siyasal pazarlama, Seçmen Davranışı, Siyasal Tutum

\title{
A Research into Political Marketing Activities on Turkish Voters in Austria
}

\begin{abstract}
Taking the concepts of politics and marketing and their practices into consideration as together has led to emergence of political marketing. Innovations and developments in political marketing are carefully examined for political success. There are lots of different factors that affect voters' decisions and behaviors. In this sense, this study aims to analyze the impact of political marketing activities on the political behavior of Turkish voters living in Austria within the context of political marketing. For this purpose, this study is separated into two parts. In the first, the definitions of the main concepts are performed and in the second part, analyzes and results of impacts of demographic factors on political behavior of the Turkish voters living in Austria are provided. The study is completed with the evaluation of the findings and recommendations for future studies. Moreover, it is believed that this study will make significant contribution to the literature and present a future projection to political parties campaigning for the voters living abroad.
\end{abstract}

Keywords: Political Marketing, Voter Behavior, Political Attitude

\section{GíRiş}

Türkçede, politika ve siyaset kelimeleri eş anlamlı olarak kullanılsalar da, etimolojik olarak incelendiklerinde köken olarak farklı kültürlerden türedikleri görülmektedir (Arslan, 2016: 7). Arapça kökenli bir kelime olan siyaset, idare etmek, at eğitimi ve seyislik anlamına gelmektedir (Devellioğlu, 2002: 959). Türkçe sözlükte, devlet işlerini düzenleme ve yürütme sanatıyla ilgili özel görüş veya anlayış olarak ifade edilmektedir (TDK, 2005: 1780). Batı dillerinde politika olarak ifade edilen siyaset (politics), eski Yunanca polis'ten (şehir, site, kent devleti) kökünden gelmekte (Fedayi, 2015: 3) ve ülke, devlet, insan yönetimi olarak kullanılmaktadır (Prelot, 1972: 5). En geniş anlamıyla siyaset, insanların hayatlarını düzenlemek için genel kuralları yapmak, korumak ve değiştirmek için gerçekleştirilen faaliyetlerin tümü olarak tanımlanmaktadır (Heywood, 2013: 22). Sosyal bir bilim dalı olarak politika, politik otorite ile ilgili kurumların oluşumu ve işlemesinde rol oynayan davranışları incelemektedir (Tan, 2002: 13). Toplumsal katmanların isteklerinin yansıtıldığı siyasal kurumlar, ellerindeki yetki ve sahip oldukları otoriteye dayalı olarak bu istekleri hakça karşılamaya çalışacaklardır. Siyaset bu isteklerin aranış ve karşılanış biçimine göre şekillenmektedir (Öztekin, 2014: 24-25). 
"Pazarlamanın Genişleyen Ekseni” başlıklı makalede Kotler ve Levy, ürünleri hizmet, mal, kişi, fikir ve örgüt olarak sınıflandırmaktadırlar. Bu çeşitlendirme doğal olarak kişi pazarlama, fikir pazarlama, toplumsal pazarlama ve örgüt pazarlama gibi yeni kavramları gündeme getirmiştir (Kotler ve Levy, 1969: 12). Pazarlama, kişilerin ve toplumun ihtiyaçlarına uygun şekilde hizmetlerin, malların ve fikirlerin üretilmesi ve geliştirilmesini, fiyatlandırmasını, dağıtımını ve satış aktivitelerini içeren planlama ve uygulama süreci olarak tanımlanmıştır (Cemalcılar, 1987: 13). Genişletilmiş tanımıyla pazarlama, sadece mal ve hizmetlerin değil, ilâveten fikirlerin de geliştirilip hedef kitlelere benimsetilmesini ve yayılmasını uygun hale getiren faaliyetler sistemi olarak kabul edilmektedir (Mucuk, 2017: 4).

Siyasal pazarlama, bir seçimi kazanmak için gerekli oyları elde etmek amacıyla kullanılan tekniklerin tamamıdır. Adayın potansiyel seçmenlerce uygunluğunun sağlanması, tanınması, rakiplerle olan farklılı̆̆ını minimal araçlarla hedefe ulaşması bu tekniklere verilebilecek örneklerdendir (Bongrad, 1992: 13). Siyasal pazarlamanın gayesi, seçime katılan bir adayı diğer adaylardan farklı göstererek, fikirlerini seçmen gözünde değerli göstermek, fertlerin davranış, düşünce ve alışkanlıklarında farklılık yaratarak ortak bir payda sağlamaktır (Atilla, 1997: 45). Siyasal pazarlama yöntemleri kullanılarak, bilgilendirme yoluyla seçmen kitlesi genişletilmekte ve insanların siyasal katılımları sağlanmaktadır. Böylece, toplum ülke sorunlarına sahip çıkmakta, iktidar icraatlarını uygularken toplumun farklı kesimlerinin tepkilerini sadece seçim dönemlerinde değil sürekli olarak dikkate almaktadır (Dağ, Servi ve Şahin, 2018; Çiftlikçi, 1996: 27).

Demokrasinin yaygınlaşması yoluyla bilgi toplumuna geçilmiş ve siyasal pazarlama önemli bir iletişim aracı olarak kullanılmıştır (Bongrad, 1992: 9). Siyasal pazarlama aracılığıla, siyasi aktörler ihtiyaç duydukları bilgilere daha teknik ve ayrıntılı bir şekilde ulaşarak, toplumun sorunlarına daha uygun çözümleri daha kolay bulmaktadırlar (Tan, 2002: 24). 

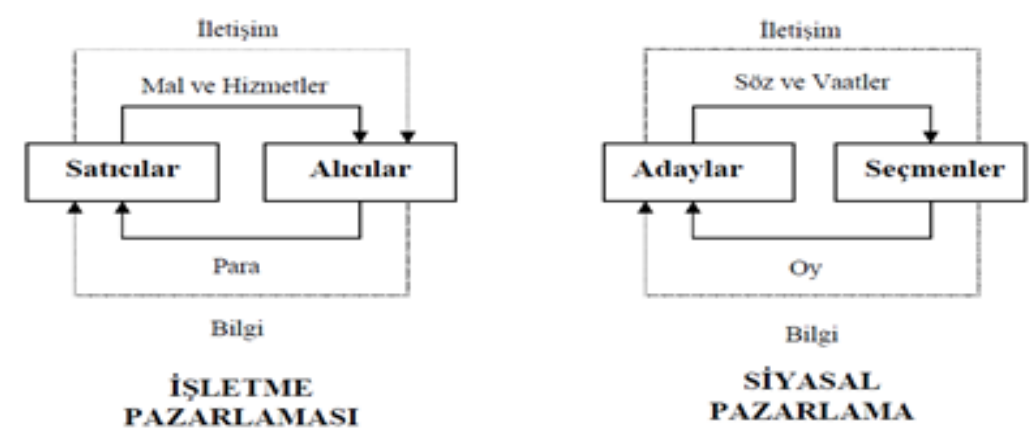

SIYASAL

PAZARLAMA

Şekil 1. Geleneksel Pazarlama ve Siyasal Pazarlama Karşılaştırması (Kotler, 1975: 763)

Şekil 1' de geleneksel ve siyasal olarak pazarlama kavramları birbirine benzeyen iki süreç olarak gösterilmektedir. Geleneksel pazarlamada alıcılar ödedikleri bedel karşılığında mal ve hizmet alırken, aradaki bağlantı bilgi ve iletişim değişimi ile gerçekleşmektedir. Siyasal alanda ise seçmenler verdikleri oylar karşıllğıında adayların verdikleri söz ve vaatleri tutmalarını beklemektedirler.

Siyasal pazarlama, mal ve hizmet pazarlaması sürecinde uygulanan tekniklerin kullanılarak, toplumun ve seçmenlerin tatmin edilmemiş istek ve ihtiyaçlarının belirlenmesi üzerine odaklanmaktadır. Sonraki süreçte bunlara cevap verecek siyasi parti programı ve adayların ortaya konması, söz konusu program ve adayların seçmenlere duyurulması ve yine bir dizi pazarlama stratejisi ile seçmenlerin ikna edilerek tercihlerini bu partiler ya da adaylardan yana kullanmalarının sağlanması şeklinde bir içeriğe sahiptir (Aslan, 2018: 112).

Siyasi aktörler, rakiplerinden farklılaşma yoluyla rakiplerine karşı üstünlük sağlamak, yeni seçmenlere ulaşmak ve hedef kitlelerinin parti sadakatlerini artırmak için pazarlama biliminden faydalanmaktadırlar. Diğer bir ifadeyle, siyasal pazarlama aktiviteleri anlamına gelen siyasal pazarlama karmasi elemanları kullanılarak, seçmenler bilgilendirilmekte ve siyasal tercihlerini daha kaliteli ve tutarlı yapmaları sağlanmaktadır (Uslu Divanoğlu, 2008: 105). Tanıtım ve tutundurma tekniklerinin ötesinde modern siyasal pazarlama kapsamında tüm pazarlama karması unsurları bir bütün olarak kullanılmaktadır (Polat, Gürbüz ve İnal, 2004: 26). Geleneksel pazarlama karması ile siyasal pazarlama karması arasında benzerlikler bulunmasına rağmen, iki kavram arasında farklılıklar da bulunmaktadır. Bu iki kavram arasındaki farklılıklar ve benzerlikler Tablo 1'de detaylı olarak gösterilmektedir. 
Tablo 1. Geleneksel Pazarlama ve Siyasal Pazarlama Karması

\begin{tabular}{|c|c|c|}
\hline $\begin{array}{l}\text { Pazarlama } \\
\text { Elemanları }\end{array}$ & Geleneksel Pazarlama & Siyasal Pazarlama \\
\hline Ürün & Mal ve hizmetler & $\begin{array}{l}\text { Parti, lider, aday, ideoloji, vaatler, } \\
\text { projeler, parti politikaları, parti } \\
\text { söylemleri, partinin kadroları vb. } \\
\text { unsurlar veya bunların bir bütünü }\end{array}$ \\
\hline Fiyat & $\begin{array}{l}\text { Değişime (mübadeleye) } \\
\text { konu mal ve hizmet için } \\
\text { verilen "para" vb. } \\
\text { maddi/fiziksel } \\
\begin{array}{l}\text { unsurdur. } \\
\end{array}\end{array}$ & $\begin{array}{l}\text { Parasal bir fiyattan söz edilemez } \\
\text { Pozitif veya negatiftir; Karşılanmış veya } \\
\text { karşılanmamış beklentiler } \\
\text { Toplumsal refah kaybı ve kazancı } \\
\text { Memnuniyet } \\
\text { Kişisel pişmanlıklar, huzursuzluklar vb. } \\
\text { psikolojik duygular } \\
\text { Toplumsal huzursuzluklar } \\
\text { Diğer partinin/adayın seçilmesi halinde } \\
\text { yapabileceği hizmetlerden kaynaklanan } \\
\text { alternatif maliyetler vb. }\end{array}$ \\
\hline Tutundurma & $\begin{array}{l}\text { Televizyon, gazete, radyo, } \\
\text { posta, e-posta, reklam } \\
\text { panosu, afiş, ilan ve } \\
\text { broşür, internet, sosyal } \\
\text { ağlar vb. her türlü } \\
\text { promosyon araçları ve } \\
\text { bunlarla gerçekleştirilen } \\
\text { faaliyetler ve diğer } \\
\text { promosyon faaliyetleri. }\end{array}$ & $\begin{array}{l}\text { Televizyon, gazete, radyo, posta, e- } \\
\text { posta, reklam panosu, afiş, ilan ve } \\
\text { broşür, internet, sosyal ağlar, miting, } \\
\text { toplantı vb. her türlü etkinlik gibi her } \\
\text { türlü promosyon araçları ve bunlarla } \\
\text { gerçekleştirilen faaliyetler ve diğer } \\
\text { promosyon faaliyetleri. }\end{array}$ \\
\hline Dağıtım/ Yer & $\begin{array}{l}\text { (Direkt ya da Endirekt) } \\
\text { Dağıtım kanalları }\end{array}$ & $\begin{array}{l}\text { Kişisel satış, seçim büroları gibi dağıtım } \\
\text { faaliyetinde ürün seçmene ulaştırılırken; } \\
\text { mitingler, parti kongresi gibi } \\
\text { faaliyetlerde seçmen ürüne ulaştırılır. } \\
\text { Televizyon, gazete, radyo, internet, } \\
\text { reklam panoları vb. tutundurma araçları } \\
\text { siyasal pazarlamada aynı zamanda birer } \\
\text { dağıtım kanalı işlevi görür. }\end{array}$ \\
\hline
\end{tabular}

Kaynak: Polat, 2015: 73

\section{Literatürdeki Siyasal Pazarlama Araştırmaları}

Kotler ve Levy (1969) "Pazarlama Kavramının Genişletilmesi (Broadening the Concept of Marketing)" adlı çalışmalarında pazarlamanın farklı alanlarda kullanımı üzerinde durmuş ve siyasal alanda adayların pazarlama faaliyetlerinden faydalanmaları gerektiğini vurgulamışlardır. Shama (1976) yılındaki "Siyasi Adayların Pazarlaması" adlı makalesinde, pazarlama ve siyasal pazarlamanın temel kavramlarını ve araçlarını özetlemiştir. Pazarlama ve siyasal pazarlamanın 
benzer kavramlar ve tarihsel özellikler göstermesi neticesinde, siyasal pazarlamanın mevcut pazarlama teorileri ile açıklanması gerektiğini savunmuştur. Benzerlik ve farklılıklarına rağmen siyasal pazarlamanın, geleneksel pazarlamanın ayrılmaz bir parçası olduğu sonucuna varmıştır.

Sitembölükbaşı (2001) araştırmasında Türk seçmenlerin parti tercihlerinde ideolojinin, lider, icraat veya parti adaylarına kıyasla daha etkili olduğunu tespit etmiş̧tir. Ayrıca seçmenlerin, eğitim seviyeleri yükseldikçe ideolojik nedenlerle oy verenlerin arttığını ortaya çıkarmıştır. Düşük eğitim düzeyine sahip seçmenlerin, oy tercihlerinde lider odaklı olduğu belirlenmiştir. Kurtuldu (2006) siyasi parti ve lider içerikli reklamların seçmenler üzerindeki etkisini incelediği araştırmasında, seçmenlerin demografik özellikler ile siyasal reklamlar arasında ilişki olduğunu tespit etmiştir.

Tura (2006) "Siyasal Pazarlamada Kullanılan Tutundurma Araçlarının Üniversite Öğrencilerinin İlgisi Üzerine Bir Araştırma” konulu çalışmasında, katılımcıların seçim kampanyalarına yaklaşımlarının gelir durumları açısından farklılık gösterdiğini tespit etmiştir. Ayrıca, yayınlanan haberlere yaklaşımların cinsiyet ve gelir durumuna göre farkl1lık gösterdiği belirlenmiştir. Ercins (2007) çalışmasında, seçmen davranışını etkileyen ekonomik faktörlerin diğer sosyolojik, psikolojik, kültürel ve ideolojik faktörlerden daha belirleyici olduğunu belirtmiştir. Halkın sağlıklı bilgilendirmesi, seçmen davranışlarının doğru analizinin siyasal partilerin başarılı olmaları için önemli olduğunu tespit etmiştir.

Güllüpunar (2010) araştırmasında seçmen tercihlerinde, kapı kapı dolaşma veya yüz yüze iletişim ile cinsiyet, eğitim ve gelir durumu arasında istatistiksel olarak anlamlı bir farklılık olduğu sonucuna ulaşmıştır. Çatlı (2011) Gazi Üniversitesi öğrencileri üzerinde yaptığı araştırmada, seçmenlerin halkla ilişkiler faaliyetlerinden ilk sırada, reklamlarından ikinci sırada ve kişisel satış ve satış geliştirme faaliyetlerinden üçüncü sırada etkilendiklerini belirlemiştir.

General (2013) "Siyasal Pazarlamada Tutundurma Faaliyetlerine İlişkin Seçmen Davranışları: Kırklareli Örneğì" başlıklı çalışmasında, seçmenlerin parti üyeliği durumunun, cinsiyet ve eğitim düzeyleri açısından farklılık gösterdiğini belirlemiştir. Ayrıca, katılımcıların vaatlerin daha inandırıcı ve gerçekçi olmasını beklediğini ve katılımcıların çoğunluğunun parti tercihlerini seçim kampanyalarından önce belirlediğini tespit etmiştir. Yılmaz (2014) "Politik Pazarlama ve Politik Pazarlama Uygulamalarına Yönelik Eğilimler: Üniversite Öğrencileri Üzerine Bir Uygulama" başlıklı çalışmasında, televizyon programlarının, mitinglerin, billboardların ve adayların ev ve kahve ziyaretlerinin seçmenleri etkilediğini tespit etmiş̧ir. Ayrıca, genç seçmenlerin ülke siyasi 
gündemiyle ilgili oldukları ve parti tercihlerinde partinin ideolojisinin öncelikli etken olduğu sonucuna ulaşmıştır.

Demirtaş ve Orçun (2015) seçimlerde ilk defa oy kullanacak lise son sınıf öğrencileri üzerine yaptıkları araştırmada, liderlerin katıldıkları tartışma programları ve mitinglerin oy vermelerini etkiledikleri sonucuna ulaşmışlardır. E-posta, radyo reklamları, telefonla aranmak, seçim otobüsleri ve dağıtılan hediyelik eşyaların genç seçmenlerin kararlarını etkilemediğini tespit etmişlerdir.

Boyraz (2016) "Seçmen kimdir, ne ister? Yerel Seçimlerde Seçmen Pazarının Bölümlendirilmesi Üzerine Bir Araştırma" başlıklı araştırmasında, adayın seçim dönemi performansı, siyasal kampanya, adayın yetkinliği, parti politikaları, adaya yakınlı, parti aidiyeti, sosyal faktörler ve adayın kimliği olmak üzere toplam sekiz faktörün yerel seçimlerde seçmenlerin oy verme davranışlarını etkilediği sonucuna ulaşmıştır.

Sarıtaş ve Bütün (2016) "Siyasi Pazarlama Faaliyetlerinin Seçmen Davranışları Açısından Önemi: Bir Uygulama" adlı çalışmalarında, yeni nesil iletişim araçları ile yapılan reklamların klasik reklamlara göre daha etkili olduğu, ekonomik faktörlerin seçmen davranışları üzerinde etkili olduğu ve siyasal pazarlama faaliyetlerinin siyasal katılımı olumlu yönde etkilediği sonuçlarına ulaşmışlardır. Qasım Ake (2017) Irak'ın başkenti Bağdat'ta yaptığ 1 çalışmada, siyasal pazarlama faaliyetlerinin Iraklı seçmenlerin davranışları üzerine etkisini incelemiştir. Araştırma sonucunda Iraklı seçmenlerin Türkiye'deki seçmenlerden farklı olarak siyasal tercihlerini seçimlerden kısa bir süre önce verdiklerini tespit etmiştir. Ayrıca, Iraklı seçmenlerin siyasi konulardaki kararlarının değişmesinin Türkiye'deki seçmenlere kıyasla daha kolay olduğu sonucuna ulaşmıştır.

Peşkircioğlu (2017) Türkiye'de seçmen davranışlarını etkileyen faktörleri üzerine yaptığı literatür taraması sonucunda, seçmenlerin medyadaki siyasi haberlerle yakından ilgilendiği ve oy verme sürecinde bu haberlerden etkilendikleri sonucuna ulaşmıştır. Özellikle, iktidarın son yıl yaptığ icraatların önem arz ettiğini tespit etmiştir. Lidere duyulan güven, adaylar ve yakın çevrenin seçmen davranışlarını etkileyen önemli faktörler olduğunu bulmuştur. Akyılmaz (2017) Almanya'da yaşayan ve seçimlerde oy kullanmayan Türkiye'li seçmen pazarının bölümlendirilmesi için yaptığı çalışma sonucunda, seçmenlerin oy verme kararlarını son bir ay içerisinde alındıklarını, seçmenlerin çoğunluğunun mitinglerin, seçmen ziyaretlerinin, sosyal medya sayfalarının ve siyasal reklamların kendilerini etkilemediğini tespit etmiştir. Ayrıca, çalışmada siyasi partilerin yurt dışındaki siyasal pazarlama faaliyetlerinin yetersiz olduğu ve parti adaylarının tanıtımlarının da eksik olduğu sonuçlarına ulaşılmıştır.

Taşdemir (2018) "Politik Pazarlama Araçlarından Tutundurma Faaliyetlerinin Seçmen Özellikleri Bakımından İncelenmesi: Gaziantep Örneği” adlı 
çalışmasında, seçmenlerin reklam faktöründen etkilenme düzeylerinde yaş grupları ve eğitim düzeyleri arasında istatistiksel olarak anlamlı bir farkl1l1k olduğunu tespit etmiştir. Ayrıca, reklam ve kampanya faktöründen etkilenme düzeyleri ve aylık gelirleri arasında anlamlı bir farklılık olduğu sonucuna ulaşmışırı. Sarsık (2019) çalışmasında, siyasi partilerin parti programları, projeleri ve siyasi vaatlerinin, seçim olmadığı dönemlerde bile seçmen tercihleri üzerinde etkili olduğunu tespit etmiştir. Ayrıca, parti örgütlerinin olası sorunlar karşısında gösterecekleri duyarlılıkların ve dini değerlerin seçmenlerin siyasi tercihini etkilediği sonucuna ulaşmıştır.

\section{YÖNTEM}

\section{Araştırmanın Amacı, Kapsamı ve Sınırlılığı}

$\mathrm{Bu}$ araştırmanın temel amacı Avusturya'da yaşayan Türkiye Cumhuriyeti vatandaşlarının siyasal davranışlarının demografik faktörlere göre nasıl değişkenlik gösterdiğinin analiz edilmesidir. Katılımcıların siyasal davranış düzeyleri, "siyasal duyarlılık", "siyasal memnuniyet" ve "kişisel tutum ve davranış" alt boyutlarında incelenmiştir. Araştırma Avusturya'da yaşayan Türkiye Cumhuriyeti vatandaşı olan seçmenleri kapsamaktadır. Araştırmada elde edilen verilerin sadece Avusturya'da yaşayan Türkiye Cumhuriyeti vatandaşı olan seçmenlerden elde edilmiş olması araştırmanın başlıca sınırlılığını oluşturmaktadır.

\section{Araştırmanın Evreni ve Örneklemi}

Avusturya'da 2019 yılında yaşayan T.C. vatandaşı sayısı Avusturya makamlarına göre 117.231 olarak verilmektedir (Mohr, 2019). 2018 yılı Haziran ayında yapılan Türkiye Cumhurbaşkanlığı seçimlerinde Avusturya'da yaşayan Türkiye Cumhuriyeti vatandaşı olan seçmen sayısı ise 106.290 olarak belirlenmiştir (YSK, 2018). Bu sayı araştırmanın evrenini oluşturmaktadır. Araştırmada örnekleme yöntemi olarak, tesadüfi olmayan örnekleme yöntemlerinden kolayda örnekleme yöntemi seçilmiştir (Yükselen, 2001: 55).

Örneklem hacminin hesaplanmasında Yilmaz (2014: 128) tarafından verilen formül kullanılmış ve 384 anketin yeterli olacağı sonucuna ulaşılmıştır. Araştırmaya duyulan güvenin artırılması için örneklem büyüklüğ̈ arttırılmış ve 500 olarak belirlenmiştir. Hazırlanan anket SurveyMonkey isimli bir online anket uygulaması ve yüz yüze görüşme tekniği ile gerçekleştirilmiştir. Araştırmada kullanılan anket formu Akyılmaz'ın (2017) çalışmasında kullandığı anketten uyarlanmıştır. Anket formu iki kısımdan oluşmaktadır. Birinci kısımda seçmenlerin siyasal davranışlarını ölçmek için ifadeler bulunmaktadır. İkinci kısımda seçmenlerin demografik özelliklerine yönelik ifadeler yer almaktadır. Tüm anketler tamamlandıktan sonra, eksik, hatalı cevaplandırılmış ya da 
cevaplandırılmamış olan 23 adet anket analiz dışı bırakılmış ve araştırma 467 anket üzerinden değerlendirilmiştir.

\section{Verilerin Analizi}

Çalışmada elde edilen veriler SPSS 21 programına kayıt edildikten sonra önce güvenirlilik analizi uygulanmış ve daha sonra frekans analizi, bağımsız iki örneklem $\mathrm{t}$ testi ve grup sayısı ikiden fazla olan durumlar için tek yönlü varyans analizi (ANOVA ) testleri yapılmıştır.

Yapılan faktör analizi sonucunda ölçeğin üç faktörlü bir yapıya sahip olduğu tespit edilmiştir. Birinci boyutta oy verme tercihinde etkili siyasal duyarlılık ile ilgili ifadeler, ikinci boyutta siyasal memnuniyet ile ilgili ifadeler ve üçüncü boyutta kişisel tutum ve değerler ile ilgili ifadeler yer almaktadır. Ölçek alt boyutlarına ait ifadeler Tablo 2'de gösterilmiştir.

Tablo 2. Yurt Dışındaki Seçmenlerin Siyasal Katılım Davranışını Belirleme Ölçeği

\begin{tabular}{|c|c|}
\hline BOYUT & ÖLÇEK MADDELERİ \\
\hline 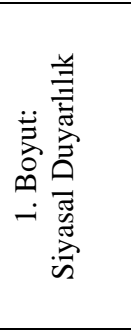 & $\begin{array}{l}\text { 1) Türkiye'deki siyasi partilere ilgi duyuyorum. } \\
\text { 2) Türkiye'deki siyasi konuları takip ediyorum. } \\
\text { 4) Türkiye'deki seçimler için oy kullanmam seçim sonuçlarını etkiler. } \\
\text { 5) Türkiye'de hangi partinin iktidar olacağı benim için önemlidir. } \\
\text { 8) Oy verirken desteklediğim partinin kazanıp kazanmayacağına bakmadan oy } \\
\text { veririm. } \\
\text { 9) Oyumu önemsiyorum. } \\
\text { 10) Oy kullanma konusunda titiz davranıyorum. } \\
\text { 13) Oy kullanılırken nelere dikkat edeceğimi biliyorum. }\end{array}$ \\
\hline 窎 & $\begin{array}{l}\text { 3) Türkiye'deki siyasi partilerin siyasal kampanyalarındaki vaatlerini yeterli } \\
\text { buluyorum. } \\
\text { 12) Mevcut siyasi sistemle sorunların çözüleceğine inanıyorum. } \\
\text { 13) Türkiye'deki siyasilerden hiçbir beklentim yoktur. } \\
\text { 16) Türkiye'deki Politikacılara güveniyorum. } \\
\text { 17) Türk siyasilerin sorunlarımızla ilgilendiğini düşünüyorum. } \\
\text { 21) Türkiye'deki siyasi partilerin siyasal kampanyalarındaki vaatlerini } \\
\text { beğeniyorum. } \\
\text { 24) Türkiye'deki siyasi partilerinin bulunduğum ülkedeki seçim çalışmalarını } \\
\text { yeterli buluyorum. }\end{array}$ \\
\hline 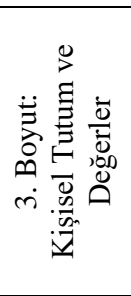 & $\begin{array}{l}\text { 15) Türkiye'deki siyasetin kutuplaştığını düşünmüyorum. } \\
\text { 20) Elde edeceğim maddi veya manevi menfaatler siyasal katılım tercihimi } \\
\text { etkiler. } \\
\text { 23) Türkiye'deki seçimlerde hangi partiye oy vereceğim konusunda kararsızlık } \\
\text { yaşıyorum. } \\
\text { 25) Oy verme kararım, partilerin seçim çalışmalarından etkilenir. } \\
\text { 26) Oy verme kararım medyadan etkilenir. } \\
\text { 27) Demokrasiye olan inancım oy kullanmamda etkilidir. }\end{array}$ \\
\hline
\end{tabular}


Elde edilen verilere istatistiksel analizler uygulanmadan önce, testin genel güvenirliği ve alt boyutlarının güvenirlik değerleri Cronbach alpha katsayısı ile değerlendirilmiştir. Anketin güvenilirlik değerleri Tablo 3'de verilmiştir. $\mathrm{Bu}$ değerlere göre verilerin güvenirlilik düzeylerinin oldukça güvenilir olduğu söylenebilir (Özdemir, 2004: 633).

Tablo 3. Anket Güvenirlik Analizi Sonuçları

\begin{tabular}{lc}
\hline Güvenirlik Analiz & Cronbach Alpha ( $\boldsymbol{\alpha})$ \\
\hline Anketin Tüm İfadelerine İlişkin & 0,840 \\
\hline Siyasal Duyarlılık & 0,883 \\
\hline Siyasal Memnuniyet & 0,801 \\
\hline Kişisel Tutum ve Davranışlar & 0,707 \\
\hline
\end{tabular}

\section{BULGULAR}

Katılımcıların demografik özellikleri Tablo 4'de gösterilmektedir.

Tablo 4. Katılımcıların Demografik Özelliklerine İlişkin Dağılımı

\begin{tabular}{|c|c|c|c|c|c|c|c|}
\hline Değişken & Alt boyut & $\mathbf{f}$ & $\%$ & Değişken & $\begin{array}{c}\text { Alt } \\
\text { boyut }\end{array}$ & f & $\%$ \\
\hline \multirow[t]{3}{*}{ Cinsiyet } & Kadın & 185 & 39,6 & \multirow{2}{*}{$\begin{array}{l}\text { Medeni } \\
\text { Durum }\end{array}$} & Evli & 360 & 77,1 \\
\hline & Erkek & 282 & 60,4 & & Bekâr & 107 & 22,9 \\
\hline & $18-25$ & 53 & 11,3 & \multirow[b]{4}{*}{ Eğitim } & $\begin{array}{c}\text { İlk ve } \\
\text { Ortaokul }\end{array}$ & 90 & 19,3 \\
\hline \multirow[t]{4}{*}{ Yaş } & $26-35$ & 180 & 38,5 & & Lise & 183 & 39,2 \\
\hline & $36-45$ & 160 & 34,3 & & Ön lisans & 64 & 13,7 \\
\hline & 46 ve üstü & 74 & 15,8 & & $\begin{array}{c}\text { Lisans ve } \\
\text { üstü }\end{array}$ & 130 & 27,8 \\
\hline & $\begin{array}{c}\text { 1.000'den } \\
\text { az }\end{array}$ & 65 & 13,9 & \multirow{4}{*}{$\begin{array}{c}\text { Yaşanan } \\
\text { Süre }\end{array}$} & $\begin{array}{c}\text { D. } \\
\text { itibaren }\end{array}$ & 93 & 19,9 \\
\hline \multirow[t]{6}{*}{$\begin{array}{c}\text { Gelir } \\
\text { (Euro) }\end{array}$} & $\begin{array}{l}1.001- \\
1.500\end{array}$ & 117 & 25,1 & & $1-15$ y1l & 118 & 25,3 \\
\hline & $\begin{array}{l}1.501- \\
2.000\end{array}$ & 136 & 29,1 & & 16-20y1l & 132 & 28,3 \\
\hline & $\begin{array}{c}2.001 \text { ve } \\
\text { üstü }\end{array}$ & 149 & 31,9 & & $\begin{array}{l}21 \text { y1l ve } \\
\text { üstü }\end{array}$ & 124 & 26,6 \\
\hline & İşçi & 227 & 48,6 & \multirow[b]{3}{*}{$\begin{array}{l}\text { Hane } \\
\text { Halkı }\end{array}$} & Yalnız & 42 & 9,0 \\
\hline & Emekli & 15 & 3,2 & & 2 & 59 & 12,6 \\
\hline & $\begin{array}{c}\text { Ev } \\
\text { Hanımı }\end{array}$ & 54 & 11,6 & & 3 & 83 & 17,8 \\
\hline
\end{tabular}




\begin{tabular}{|c|c|c|c|c|c|c|}
\hline \multirow[t]{4}{*}{ Meslek } & Öğrenci & 29 & 6,2 & 4 & 150 & 32,1 \\
\hline & $\begin{array}{c}\text { Esnaf \& } \\
\text { İşveren }\end{array}$ & 85 & 18,2 & 5 ve üstü & 133 & 28,5 \\
\hline & $\begin{array}{c}\text { Kamu } \\
\text { Çalışanı }\end{array}$ & 47 & 10,1 & & & \\
\hline & Diğer & 10 & 2,1 & & & \\
\hline
\end{tabular}

Tablo 4'te katılımcıların demografik özellikleri incelendiğinde; katılımcıların \%60,4'ünün erkek, \%38,5'inin 26-35 yaş aralığında, \%31,9'unun aylık ortalama gelirinin $2.001 €$ ve üstünde, \%77,1'nin evli, \%28,3’ünün 16-20 yıl arasında Avusturya'da ikamet ettiği, \%39,2'sinin lise mezunu, \%32,1'nin 4 kişilik hanelerde oturduğu ve \%48,6'sının işçi olduğu tespit edilmiştir.

Tablo 5. Katılımcıların Siyasal Davranış ile Cinsiyet Değişkenine Göre Bağımsız T Testi Sonuçları

\begin{tabular}{lccccc}
\hline Alt Boyutlar & Cinsiyet & N & Ort. & t & p \\
\hline Siyasal Duyarlıık & Kadın & 185 & 4,10 & $-1,878$ &, 061 \\
\cline { 2 - 6 } & Erkek & 282 & 4,24 & & \\
\hline Siyasal Memnuniyet & Kadın & 185 & 3,18 & 0,604 &, 546 \\
\cline { 2 - 6 } & Erkek & 282 & 3,13 & & \\
\hline Kişisel Tutum ve Davranış & Kadın & 185 & 2,82 & 0,847 &, 397 \\
\cline { 2 - 6 } & Erkek & 282 & 2,75 & & \\
\hline
\end{tabular}

"Cinsiyet ile seçmenlerin siyasal davranışları arasında anlamlı bir fark vardır" hipotezi, Tablo 5'te elde edilen $t$ testi sonuçlarına göre, tüm alt boyutlarda desteklenmemektedir $(p>0,05)$. Cinsiyete göre katılımcıların arasında siyasal duyarlılık, siyasal memnuniyet ve kişisel tutum ve davranış alt boyutlarında istatistiksel olarak anlamlı bir fark tespit edilmemiştir.

Tablo 6. Katılımcıların Siyasal Davranış ile Medeni Durum Değişkenine Göre Bağımsız T Testi Sonuçları

\begin{tabular}{lccccc}
\hline Alt Boyutlar & $\begin{array}{c}\text { Medeni } \\
\text { Durum }\end{array}$ & N & Ort. & t & P \\
\hline Siyasal Duyarlılık & Evli & 360 & 4,21 & 1,256 &, 211 \\
\cline { 2 - 6 } & Bekar & 107 & 4,10 & & \\
\hline Siyasal Memnuniyet & Evli & 360 & 3,18 & 1,360 &, 176 \\
\hline Kişisel Tutum ve Davranış & Bekar & 107 & 3,05 & & \\
\cline { 2 - 6 } & Evli & 360 & 2,78 & 0,112 &, 911 \\
\cline { 2 - 6 } & Bekar & 107 & 2,77 & & \\
\hline
\end{tabular}


"Medeni durum ile seçmenlerin siyasal davranışları arasında anlamlı bir fark vardır." hipotezi, Tablo 6'da elde edilen t testi sonuçlarına göre, tüm alt boyutlarda desteklenmemektedir $(\mathrm{p}>0,05)$. Medeni duruma göre katılımcıların arasında siyasal duyarlılık, siyasal memnuniyet ve kişisel tutum gruplarında istatistiksel olarak anlamlı bir farklılık tespit edilmemiştir.

Tablo 7. Siyasal Davranış ile Katılımcıların Yaşları Arasındaki Anlamlı Farka İlişkin Tek Yönlü ANOVA Analizi Sonuçları

\begin{tabular}{|c|c|c|c|c|c|c|c|}
\hline & & $\begin{array}{c}\text { Say } \\
1\end{array}$ & $\begin{array}{c}\text { Ort } \\
.\end{array}$ & Std. & $\mathbf{F}$ & $\mathbf{P}$ & $\begin{array}{l}\text { Anlam } \\
\text { li Fark }\end{array}$ \\
\hline \multirow{5}{*}{$\begin{array}{c}\text { Siyasal } \\
\text { Duyarlılık }\end{array}$} & $18-25$ (a) & 53 & 4,00 & 0,818 & \multirow{4}{*}{1,330} & \multirow{4}{*}{0,264} & --- \\
\hline & 26-35 (b) & 180 & 4,21 & 0,705 & & & --- \\
\hline & $36-45$ (c) & 160 & 4,25 & 0,827 & & & --- \\
\hline & $\begin{array}{l}46 \text { ve üstü } \\
\text { (d) }\end{array}$ & 74 & 4,15 & 0,936 & & & --- \\
\hline & Toplam & 467 & 4,19 & 0,801 & & & ---- \\
\hline \multirow{5}{*}{$\begin{array}{c}\text { Siyasal } \\
\text { Memnuniy } \\
\text { et }\end{array}$} & $18-25$ (a) & 53 & 3,01 & 0,627 & \multirow{4}{*}{4,13} & \multirow{4}{*}{$\begin{array}{c}\mathbf{0 , 0 0 7} \\
*\end{array}$} & $\mathrm{~d}$ \\
\hline & 26-35 (b) & 180 & 3,21 & 0,741 & & & $\mathrm{~d}$ \\
\hline & $36-45$ (c) & 160 & 3,36 & 0,890 & & & Yok \\
\hline & $\begin{array}{l}46 \text { ve üstü } \\
\text { (d) }\end{array}$ & 74 & 3,05 & 0,840 & & & a ve b \\
\hline & Toplam & 467 & 3,18 & 0,771 & & & ---- \\
\hline \multirow{5}{*}{$\begin{array}{l}\text { Kişisel } \\
\text { Tutum ve } \\
\text { Davranış }\end{array}$} & $18-25$ (a) & 53 & 3,10 & 1,012 & \multirow{4}{*}{1,517} & \multirow{4}{*}{$\begin{array}{c}\mathbf{0 , 0 0 0} \\
*\end{array}$} & $d$ \\
\hline & 26-35 (b) & 180 & 3,16 & 0,983 & & & $\mathrm{~d}$ \\
\hline & $36-45$ (c) & 160 & 3,57 & 0,974 & & & $\mathrm{~d}$ \\
\hline & $\begin{array}{l}46 \text { ve üstü } \\
\text { (d) }\end{array}$ & 74 & 3,05 & 1,017 & & & $\begin{array}{c}a, b \text { ve } \\
\text { c }\end{array}$ \\
\hline & Toplam & 467 & 3,23 & 1,013 & & & ---- \\
\hline
\end{tabular}

Tablo 7'de tek yönlü varyans analizi (ANOVA) testi sonuçlarına göre, "Yaş ile seçmenlerin siyasal davranışları arasında anlamlı bir fark vardır." hipotezinin alt boyutlarından "siyasal duyarlıl1k" alt boyutunda istatistiksel olarak anlamlı bir fark tespit edilmezken, "siyasal memnuniyet" ve "kişisel tutum ve davranış" alt boyutlarında 36-45 yaş aralığındaki katılımcılar lehine anlamlı bir fark elde edilmiştir $(p<0,05)$. Bu durumda hipotez kısmen kabul edilmektedir. 
Tablo 8. Siyasal Davranış ile Katılımcıların İkamet Süreleri Arasındaki Anlamlı Farka İlişkin Tek Yönlü ANOVA Analizi Sonuçları

\begin{tabular}{|c|c|c|c|c|c|c|c|}
\hline & & Sayı & Ort. & Std. & $\mathbf{F}$ & $\mathbf{P}$ & $\begin{array}{c}\text { Anlamlı } \\
\text { Fark }\end{array}$ \\
\hline \multirow{5}{*}{$\begin{array}{c}\text { Siyasal } \\
\text { Duyarlılık }\end{array}$} & Doğum yeri (a) & 93 & 4,20 & 0,740 & \multirow{5}{*}{0,751} & \multirow{4}{*}{0,522} & --- \\
\hline & $1-15$ (b) & 118 & 4,15 & 0,762 & & & --- \\
\hline & $16-20$ (c) & 132 & 4,28 & 0,778 & & & --- \\
\hline & 21 ve üstü (d) & 124 & 4,15 & 0,901 & & & --- \\
\hline & Toplam & 467 & 4,19 & 0,801 & & & ---- \\
\hline \multirow{5}{*}{$\begin{array}{c}\text { Siyasal } \\
\text { Memnuniyet }\end{array}$} & Doğum yeri (a) & 93 & 3,08 & 0,820 & \multirow{4}{*}{1,648} & \multirow{4}{*}{0,178} & --- \\
\hline & $1-15$ (b) & 118 & 3,04 & 0,809 & & & --- \\
\hline & $16-20$ (c) & 132 & 3,17 & 0,846 & & & ---- \\
\hline & 21 ve üstü (d) & 124 & 3,28 & 1,005 & & & ---- \\
\hline & Toplam & 467 & 3,15 & 0,879 & & & ---- \\
\hline \multirow{5}{*}{$\begin{array}{c}\text { Kişisel } \\
\text { Tutum ve } \\
\text { Davranış }\end{array}$} & Doğum yeri (a) & 93 & 2,71 & 0,883 & \multirow{4}{*}{4,948} & \multirow{4}{*}{ 0,002* } & $\mathrm{D}$ \\
\hline & $1-15$ (b) & 118 & 2,80 & 0,662 & & & Yok \\
\hline & $16-20$ (c) & 132 & 2,61 & 0,799 & & & $\mathrm{D}$ \\
\hline & 21 ve üstü (d) & 124 & 2,99 & 0,941 & & & a ve c \\
\hline & Toplam & 467 & 2,78 & 0,836 & & & ---- \\
\hline
\end{tabular}

Tablo 8'deki tek yönlü varyans analizi (ANOVA) testi sonuçlarına göre, "Avusturya'daki ikamet süresi ile seçmenlerin siyasal davranışları arasında anlamlı bir fark vardır." hipotezi, "siyasal duyarlılı" ve siyasal memnuniyet" alt boyutlarında istatistiksel olarak anlamlı bir fark elde edilmezken, "kişisel tutum ve davranış" alt boyutunda 21 yaş ve üstü olanlar lehine anlamlı bir fark tespit edilmiştir $(\mathrm{p}<0,05)$. Bu durumda hipotez kısmen desteklenmektedir.

Tablo 9. Siyasal Davranış ile Katılımcıların Eğitim Düzeyleri Arasındaki Anlamlı Farka İlişsin Tek Yönlü ANOVA Analizi Sonuçları

\begin{tabular}{|c|c|c|c|c|c|c|c|}
\hline & & Sayı & Ort. & Std. & $\mathbf{F}$ & $\mathbf{P}$ & $\begin{array}{c}\text { Anlamlı } \\
\text { Fark }\end{array}$ \\
\hline \multirow{5}{*}{$\begin{array}{c}\text { Siyasal } \\
\text { Duyarlılık }\end{array}$} & İlk- Ortaokul (a) & 90 & 4,05 & 0,974 & \multirow{4}{*}{1,061} & \multirow{4}{*}{0,366} & --- \\
\hline & Lise (b) & 183 & 4,24 & 0,684 & & & --- \\
\hline & Önlisans (c) & 64 & 4,22 & 0,715 & & & --- \\
\hline & Lisans ve üstü (d) & 130 & 4,20 & 0,859 & & & --- \\
\hline & Toplam & 467 & 4,19 & 0,801 & & & ---- \\
\hline \multirow{8}{*}{$\begin{array}{c}\text { Siyasal } \\
\text { Memnuniyet }\end{array}$} & İlk- Ortaokul (a) & 90 & 3,26 & 0,921 & \multirow{4}{*}{0,864} & \multirow{4}{*}{0,460} & --- \\
\hline & Lise (b) & 183 & 3,15 & 0,776 & & & --- \\
\hline & Önlisans (c) & 64 & 3,13 & 0,949 & & & ---- \\
\hline & Lisans ve üstü (d) & 130 & 3,07 & 0,949 & & & ---- \\
\hline & Toplam & 467 & 3,15 & 0,879 & & & ---- \\
\hline & İlk- Ortaokul (a) & 90 & 3,01 & 0,895 & \multirow[b]{3}{*}{3,865} & \multirow[b]{3}{*}{$0,009 *$} & $\mathrm{C}$ \\
\hline & Lise (b) & 183 & 2,74 & 0,797 & & & Yok \\
\hline & Önlisans (c) & 64 & 2,56 & 0,737 & & & A \\
\hline
\end{tabular}




\begin{tabular}{cccccc}
\hline $\begin{array}{c}\text { Kişisel } \\
\text { Tutum ve } \\
\text { Davranış }\end{array}$ & Lisans ve üstü (d) & 130 & 2,79 & 0,866 & Yok \\
\hline & Toplam & 467 & 2,78 & 0,836 & ---- \\
\hline
\end{tabular}

Tablo 9'da tek yönlü varyans analizi (ANOVA) testi sonuçları incelendiğinde, "Eğitim düzeyi ile seçmenlerin siyasal davranışları arasında anlamlı bir fark vardır." hipotezinde, "siyasal duyarlılık" ve siyasal memnuniyet" alt boyutlarında istatistiksel olarak anlamlı bir fark elde edilmezken, "kişisel tutum ve davranış" alt boyutunda ilk ve ortaokul mezunları lehine anlamlı bir fark tespit edilmiştir $(\mathrm{p}<0,05)$. Bu durumda hipotez kismen kabul edilmektedir.

Tablo 10. Siyasal Davranış ile Katılımcıların Aylık Gelirleri Arasındaki Anlamlı Farka İlişkin Tek Yönlü ANOVA Analizi Sonuçları

\begin{tabular}{|c|c|c|c|c|c|c|c|}
\hline & & Sayı & Ort. & Std. & $\mathbf{F}$ & $\mathbf{P}$ & $\begin{array}{c}\text { Anlamlı } \\
\text { Fark }\end{array}$ \\
\hline \multirow{5}{*}{$\begin{array}{c}\text { Siyasal } \\
\text { Duyarlılık }\end{array}$} & 1.001 den az (a) & 65 & 4,05 & 0,917 & \multirow{4}{*}{2,779} & \multirow{4}{*}{0,051} & --- \\
\hline & $1.001-1.500$ (b) & 117 & 4,09 & 0,856 & & & --- \\
\hline & $1.501-2.000$ (c) & 136 & 4,18 & 0,793 & & & --- \\
\hline & 2.001 ve üstü (d) & 149 & 4,33 & 0,688 & & & --- \\
\hline & Toplam & 467 & 4,19 & 0,801 & & & ---- \\
\hline \multirow{4}{*}{$\begin{array}{c}\text { Siyasal } \\
\text { Memnuniyet }\end{array}$} & 1.001 den az (a) & 65 & 3,23 & 0,860 & \multirow{4}{*}{0,781} & \multirow{4}{*}{0,505} & --- \\
\hline & $1.001-1.500(b)$ & 117 & 3,13 & 0,961 & & & --- \\
\hline & $1.501-2.000(\mathrm{c})$ & 136 & 3,21 & 0,748 & & & ---- \\
\hline & 2.001 ve üstü (d) & 149 & 3,07 & 0,931 & & & ---- \\
\hline \multirow{6}{*}{$\begin{array}{c}\text { Kişisel } \\
\text { Tutum ve } \\
\text { Davranış }\end{array}$} & Toplam & 467 & 3,15 & 0,879 & & & ---- \\
\hline & 1.001 den az (a) & 65 & 3,18 & 0,825 & \multirow{4}{*}{7,209} & \multirow{4}{*}{$0,000 *$} & $a, b$ ve $c$ \\
\hline & $1.001-1.500$ (b) & 117 & 2,77 & 0,807 & & & A \\
\hline & $1.501-2.000$ (c) & 136 & 2,77 & 0,734 & & & A \\
\hline & 2.001 ve üstü (d) & 149 & 2,62 & 0,898 & & & $\mathrm{~A}$ \\
\hline & Toplam & 467 & 2,78 & 0,836 & & & ---- \\
\hline
\end{tabular}

Tablo 10’daki tek yönlü varyans analizi (ANOVA) testi sonuçlarına göre, "Gelir durumu ile seçmenlerin siyasal davranışları arasında anlamlı bir fark vardır." hipotezinde, "siyasal duyarlılık" ve siyasal memnuniyet" alt boyutlarında istatistiksel olarak anlamlı bir fark elde edilmezken, "kişisel tutum ve davranış" alt boyutunda aylık geliri 1.001 Euro'dan az olanlar lehine anlamlı bir fark tespit edilmiştir $(\mathrm{p}<0,05)$. Bu durumda hipotez kısmen desteklenmektedir. 
Tablo 11. Siyasal Davranış ile Katılımcıların Hane Halkı Büyüklüğü Arasındaki Anlamlı Farka İlişsin Tek Yönlü ANOVA Analizi Sonuçları

\begin{tabular}{|c|c|c|c|c|c|c|c|}
\hline & & Sayı & Ort. & Std. & $\mathbf{F}$ & $\mathbf{P}$ & $\begin{array}{c}\text { Anlamlı } \\
\text { Fark }\end{array}$ \\
\hline \multirow{6}{*}{$\begin{array}{c}\text { Siyasal } \\
\text { Duyarlılık }\end{array}$} & Yalnız yaşıyor (a) & 42 & 4,20 & 0,917 & \multirow{4}{*}{0,475} & \multirow{4}{*}{0,754} & --- \\
\hline & 2 (b) & 59 & 4,19 & 0,856 & & & --- \\
\hline & 3 (c) & 83 & 4,20 & 0,793 & & & --- \\
\hline & $4(d)$ & 150 & 4,11 & 0,688 & & & --- \\
\hline & 5 ve üstü (e) & 133 & 4,24 & & & & ---- \\
\hline & Toplam & 467 & 4,19 & 0,801 & & & \\
\hline \multirow{6}{*}{$\begin{array}{c}\text { Siyasal } \\
\text { Memnuniyet }\end{array}$} & Yalnız yaşıyor (a) & 42 & 3,24 & 0,860 & \multirow{4}{*}{0,430} & \multirow{4}{*}{0,787} & --- \\
\hline & 2 (b) & 59 & 3,18 & 0,961 & & & --- \\
\hline & 3 (c) & 83 & 3,15 & 0,748 & & & ---- \\
\hline & $4(\mathrm{~d})$ & 150 & 3,07 & 0,931 & & & ---- \\
\hline & 5 ve üstü (e) & 133 & 3,18 & & & & \\
\hline & Toplam & 467 & 3,15 & 0,879 & & & ---- \\
\hline \multirow{6}{*}{$\begin{array}{l}\text { Kişisel } \\
\text { Tutum ve } \\
\text { Davranış }\end{array}$} & Yalnız yaşıyor (a) & 42 & 2,89 & 0,825 & \multirow{5}{*}{1,501} & \multirow{5}{*}{0,201} & --- \\
\hline & 2 (b) & 59 & 2,95 & 0,807 & & & --- \\
\hline & $3(\mathrm{c})$ & 83 & 2,81 & 0,734 & & & --- \\
\hline & 4 (d) & 150 & 2,76 & 0,898 & & & --- \\
\hline & 5 ve üstü (e) & 133 & 2,67 & & & & \\
\hline & Toplam & 467 & 2,78 & 0,836 & & & ---- \\
\hline
\end{tabular}

Tablo 11'deki tek yönlü varyans analizi (ANOVA) testi sonuçları incelendiğinde, "Hane halkı büyüklüğü ile seçmenlerin siyasal davranışları arasında anlamlı bir fark vardır." hipotezinde, tüm alt boyutlarda istatistiksel olarak anlamlı bir fark elde edilmemiştir $(\mathrm{p}>0,05)$. Bu durumda hipotez tamamen reddedilmektedir.

Tablo 12. Siyasal Davranış ile Katılımcıların Meslekleri Arasındaki Anlamlı Farka İlişkin Tek Yönlü ANOVA Analizi Sonuçları

\begin{tabular}{|c|c|c|c|c|c|c|c|}
\hline & & Sayı & Ort. & Std. & $\mathbf{F}$ & $\mathbf{P}$ & $\begin{array}{c}\text { Anlamlı } \\
\text { Fark }\end{array}$ \\
\hline \multirow{9}{*}{$\begin{array}{c}\text { Siyasal } \\
\text { Duyarlılık }\end{array}$} & İşçi (a) & 227 & 4,19 & 0,797 & \multirow{7}{*}{1,539} & \multirow{7}{*}{0,164} & --- \\
\hline & Emekli (b) & 15 & 4,13 & 0,858 & & & --- \\
\hline & Ev Hanımı (c) & 54 & 4,15 & 0,822 & & & --- \\
\hline & Öğrenci (d) & 29 & 3,81 & 0,913 & & & --- \\
\hline & $\begin{array}{l}\text { Esnaf ve } \\
\text { İşveren (e) }\end{array}$ & 85 & 4,26 & 0,814 & & & ---- \\
\hline & $\begin{array}{c}\text { Devlet } \\
\text { Kurumu (f) }\end{array}$ & 47 & 4,34 & 0,667 & & & --- \\
\hline & Diğer (g) & 10 & 4,25 & 0,674 & & & ---- \\
\hline & Toplam & 467 & 4,19 & 0,801 & & & ---- \\
\hline & İşçi (a) & 227 & 3,15 & 0,821 & & & $\mathrm{~B}$ \\
\hline
\end{tabular}




\begin{tabular}{|c|c|c|c|c|c|c|c|}
\hline \multirow{7}{*}{$\begin{array}{c}\text { Siyasal } \\
\text { Memnuniyet }\end{array}$} & Emekli (b) & 15 & 4,02 & 0,918 & \multirow{6}{*}{3,402} & \multirow{6}{*}{$0,003^{*}$} & a,c,d,e,f,g \\
\hline & Ev Hanımı (c) & 54 & 3,16 & 0,907 & & & B \\
\hline & Öğrenci (d) & 29 & 2,85 & 0,955 & & & B \\
\hline & $\begin{array}{l}\text { Esnaf ve } \\
\text { İşveren (e) }\end{array}$ & 85 & 3,09 & 0,941 & & & B \\
\hline & $\begin{array}{c}\text { Devlet } \\
\text { Kurumu (f) }\end{array}$ & 47 & 3,22 & 0,812 & & & B \\
\hline & Diğer (g) & 10 & 2,87 & 0,874 & & & B \\
\hline & Toplam & 467 & 3,15 & 0,879 & & & ---- \\
\hline \multirow{8}{*}{$\begin{array}{l}\text { Kişisel } \\
\text { Tutum ve } \\
\text { Davranış }\end{array}$} & İşçi (a) & 227 & 2,67 & 0,790 & \multirow{8}{*}{5,803} & \multirow{7}{*}{$0,000^{*}$} & B \\
\hline & Emekli (b) & 15 & 3,87 & 0,722 & & & a,c,d,e,f,g \\
\hline & Ev Hanımı (c) & 54 & 2,89 & 0,864 & & & B \\
\hline & Öğrenci (d) & 29 & 2,85 & 0,752 & & & B \\
\hline & $\begin{array}{l}\text { Esnaf ve } \\
\text { İşveren (e) }\end{array}$ & 85 & 2,86 & 0,899 & & & B \\
\hline & $\begin{array}{c}\text { Devlet } \\
\text { Kurumu (f) }\end{array}$ & 47 & 2,60 & 0,791 & & & B \\
\hline & Diğer (g) & 10 & 2,73 & 0,498 & & & B \\
\hline & Toplam & 467 & 2,78 & 0,836 & & & ---- \\
\hline
\end{tabular}

Tablo 12'deki tek yönlü varyans analizi (ANOVA) testi sonuçlarına göre, "Meslekler ile seçmenlerin siyasal davranışları arasında anlamlı bir fark vardır." hipotezinde, alt boyutlardan "siyasal duyarlıl1k" boyutunda istatistiksel olarak anlamlı bir farkl1lık tespit edilmezken, "siyasal memnuniyet" ve "kişisel tutum ve davranış" boyutlarında emekli olan katılımcılar lehine anlamlı bir fark elde edilmiştir $(\mathrm{p}<0,05)$. Bu durumda hipotez kısmen desteklenmektedir.

\section{SONUÇ ve TARTIŞMA}

Siyasal pazarlama faaliyetlerinin profesyonel anlamda Türkiye’de 1980'li yıllardan sonra uygulandığ 1 görülmektedir. Siyasal pazarlama alanında yapılan akademik ve profesyonel araştırmalar her geçen gün artmaktadır. Bu çalışma, Avusturya'da yaşayan Türkiye Cumhuriyeti vatandaşlarının siyasal davranışlarının tespit edilmesi ile hem akademik alanda hem de profesyonel siyaset bilimciler açısından ayrı bir öneme sahiptir. Özellikle farklı ülkelerde yaşayan seçmenlerin siyasal eğilimlerinin tespit edilmesi siyasal partiler için artan rekabet ortamında başarı sağlamak için yol gösterici olacaktır.

Sürekli değişen seçmen istek ve ihtiyaçlarına uygun cevaplar bulabilmek için pazarlama karması elemanları olan ürün, fiyat, dağıtım ve tutundurma faaliyetlerine siyaset alanında da başvurulmaktadır. Siyasal pazarlama da amaç sadece seçim dönemlerinde seçmenlerden oy almak değil, daha uzun süreli ilişkiler kurarak sürekli bir iletişim ve etkileşim oluşturmaktır. 
Seçmenlerin, cinsiyet ve medeni durumlarına göre siyasal davranışları ve alt boyutlarında istatistiksel olarak anlamlı bir farklılık tespit edilmemiştir. $\mathrm{Bu}$ verilere göre, siyasal partilerin veya aktörlerin planladıkları faaliyetlerde, cinsiyet ve medeni durum demografik değişkenlerine göre stratejiler geliştirmelerinin gerekli olmayacağı söylenebilir.

Ankete katılanların yaş değişkeni ve mesleklerine göre ANOVA sonuçlarına bakıldığında, "siyasal duyarlılık" alt boyutunda istatistiksel olarak anlamlı bir fark görülmezken, "siyasal memnuniyet" ve "kişisel tutum ve davranış" alt boyutlarında anlamlı bir farklılık tespit edilmiştir.

Katılımcıların ikamet süreleri, eğitim düzeyleri ve aylık gelirlerine göre ANOVA testi sonuçları incelendiğinde, "kişisel tutum ve davranış" alt boyutunda istatistiksel olarak anlamlı bir farklılık tespit edilmiştir.

Yurtdışında yaşayan seçmenlere yönelik daha sonra yapılacak siyasal pazarlama çalışmalarında ülkenin kendine özgü unsurlarını da dikkate alarak bilimsel ölçek geliştirme süreci sonucunda oluşturulacak ölçek ile bir çalışma yapılması akademik açıdan katma değer oluşturacaktır.

Sonuç olarak siyasi partilerin ve adayların farklı ülkelerde yaşayan seçmenlere göre farklı siyasal pazarlama faaliyetleri uygulamaları geliştirmeleri siyasal başarıları için gerekli olduğu söylenebilir. Siyasal pazarlamanın, tarihsel süreç içerisindeki gelişimi incelendiğinde, gelecekte pazarlama uygulamalarının siyaset alanında daha fazla rol oynayacağı söylenebilir. Değişen seçmen davranışlarının belli aralıklarla analiz edilmesi siyasi partilerin ve adayların uygulayacakları siyasal pazarlama faaliyetleri belirlenmesinde rehberlik edecektir. Farklı alanlardaki çalışmaların karşılaştırılması ve birlikte analiz edilmesi de bu konuda yardımcı olacaktır.

Çalışma sonucunda elde edilen sonuçların gelecekte yapılacak araştırmalar için bir alt yap1 oluşturacağı düşünülmektedir. Ayrıca, gelecekte yapılacak çalışmaların farklı ülkelerde, benzer veya farklı örneklemler üzerinde çalışılması genel bir siyasal katılım tespiti açısından önemli görülmektedir.

\section{KAYNAKÇA}

Akyılmaz, B. (2017). Almanyada'ki oy vermeyen Türk seçmen pazarının bölümlendirilmesi üzerine bir araştırma, Yayınlanmış Doktora Tezi, Hasan Kalyoncu Üniversites.

Arslan, R. (2016). Siyaset Bilimine Giriş (1. bs.), Dora Basım-Yayın Dağıtım Ltd. Şti. 
Aslan, R. (2018). Siyasal Pazarlama. İçinde Y. Akçi (Ed.), değişen pazarlama anlayışı: güncel pazarlama yaklaşımları (ss. 103-136), Gazi Kitabevi.

Atilla, N. (1997), Politika pazarlaması (Örnekleriyle Türkiye'de politika pazarlaması ve bir kampanya araçları etkinlik araştırması), Yayınlanmış Yüksek Lisans Tezi, Uludağ Üniversitesi.

Bongrad, M. (1992). Politikada pazarlama, Çev., Fatma Ersoy, İletişim Yayınlar,

Boyraz, E. (2016). Seçmen kimdir, ne ister? Yerel seçimlerde seçmen pazarının bölümlendirilmesi üzerine bir araştırma, Atatürk Üniversitesi Ikktisadi ve İdari Bilimler Dergisi, 31(1), 1-28.

Cemalcılar, İ. (1987), Pazarlama'nın tanımı, Pazarlama Dünyası, 1(5).

Çatlı, A. (2011), Politik pazarlamada tutundurma faaliyetlerinin üniversite öğrencileri tarafindan algılanışı, Yayınlanmış Yüksek Lisans Tezi, Gazi Üniversitesi.

Çiftlikçi, A. (1996). Siyaset pazarlaması ve siyasi partilerin Malatya'daki uygulamaları, Yayınlanmış Yüksek Lisans Tezi, İnönü Üniversitesi.

Dağ, R., Servi, T. ve Şahin, F. (2018). Katılımcı demokrasi ve aktif vatandaşlık: Adıyaman örneği, Dicle Üniversitesi Sosyal Bilimler Dergisi, 10(20), 294-303.

Demirtaş, M. C. ve Orçun, Ç. (2015). Siyasal pazarlama uygulamalarının ilk kez oy kullanacak seçmenler üzerindeki etkilerine yönelik bir araştırma, Karamanoğlu Mehmetbey Üniversitesi Sosyal ve Ekonomik Araştırmalar Dergisi, 17(28), 41-48.

Devellioğlu, F. (2002). Osmanlıca Türkçe ansiklopedik Lûgat, Aydın Kitabevi.

Ercins, G. (2007). Türkiye'de sosyo-ekonomik faktörlere bağlı olarak değişen seçmen davranışı, C.Ü. İktisadi ve İdari Bilimler Dergisi, 8(2), 25-40.

Fedayi, C.l (2015). Siyaset Bilimi (5. bs.), Kadim Yayınlar1.

General, C. A. (2013). Siyasal pazarlamada tutundurma faaliyetlerine ilişkin seçmen davranışları: Kırklareli örneği, Yayınlanmış Yüksek Lisans Tezi, Sütçü İmam Üniversitesi.

Güllüpunar, H. (2010), Siyasal iletişim ve aday imajı, Eğitim Kitabevi.

Heywood, A. (2013), Siyaset, Çev., B. B. Özipek. (4. bs.). Adres Yayınları. 
Kotler, P. ve Levy, S. J. (1969), Broadening the concept of marketing, Journal of Marketing, 33(1), 10-15.

Kotler, P. (1975). Overview of political candidate marketing, ACR North American Advances, 2, 761-769.

Kurtuldu, H. S. (2006). Politik parti ve politik lider reklamları, Dokuz Eylül Üniversitesi Sosyal Bilimler Enstitüsü Dergisi, 8(1), 292-306.

Mucuk, İ. (2017). Pazarlama ilkeleri, Türkmen Kitabevi.

Özdemir, K. (2004). Paket programlar ile istatistiksel veri analizi (5. bs.). Kaan Kitabevi.

Öztekin, A. (2014). Siyaset Bilimine Giriş (9. bs.). Siyasal Kitabevi.

Peşkircioğlu, H. İ. (2017). Türkiye'de seçmen davranışı literatürü üzerine analitik bir çalışma, Yayınlanmış Yüksek Lisans Tezi, Bahçeşehir Üniversitesi.

Polat, C. (2015). Siyasal pazarlama ve Illetişim, Nobel Akademik Yayıncılık.

Polat, C., Gürbüz, E. ve İnal, M. E. (2004). Hedef seçmen siyasal pazarlama yaklaşımı, Nobel Yayıncılık.

Prelot, M. (1972). Politika Bilimi, Çev., N. Önal. Varlık Yayınları.

Qasım A., Mohanad A. R. (2017). Siyasal pazarlama faaliyetlerinin seçmen davranışlarına etkisi üzerine bir araştırma, Yayınlanmış Yüksek Lisans Tezi. Süleyman Demirel Üniversitesi.

Mohr, M. (2019). Anzahl der Türken in Österreich. https://de.statista.com/statistik/daten/studie/587860/umfrage/tuerken-inoesterreich/ (01.11.2019).

Sarıtaş, A. ve Bütün, R. U. (2016). Siyasi pazarlama faaliyetlerinin seçmen davranışları açısından önemi: Bir uygulama, Süleyman Demirel Üniversitesi Sosyal Bilimler Enstitüsü Dergisi, 25, 127-156.

Sarsık, A. (2019). Siyasal pazarlama: Zonguldak ilinde seçmen davranışı üzerine bir araştırma, Yayınlanmış Yüksek Lisans Tezi, Bülent Ecevit Üniversitesi.

Shama, A. (1976). The marketing of political candidates, Journal of the Academy of Marketing Science, 4(4), 764-777. 
Sitembölükbaşı, Ş. (2001). Parti seçmenlerinin siyasal yönelimlerine etki eden sosyo ekonomik faktörler, Nobel Yayın.

Tan, A. (2002). Ilke ve uygulamalariyla politik pazarlama, Papatya Yayınc1lık.

Taşdemir, M. (2018). Politik pazarlama araçlarından tutundurma faaliyetlerinin seçmen özellikleri bakımından incelenmesi: Gaziantep örneği, Yayınlanmış Yüksek Lisans Tezi, Gaziantep Üniversitesi.

Tura, B. (2006). Siyasal pazarlamada kullanılan tutundurma araçlarına üniversite ögrencilerinin ilgisi üzerine bir araştırma, Yayınlanmış Yüksek Lisans Tezi, Gazi Üniversitesi.

Türk Dil Kurumu. (2005). Türkçe Sözlük (10. bs.). Atatürk Kültür, Dil ve Tarih Yüksek Kurumu, Ankara.

Uslu Divanoğlu, S. (2008). Seçim kampanyalarında siyasal pazarlama karması elamanlarının yeri ve önemi, Niğde Üniversitesi İktisadi ve İdari Bilimler Fakültesi Dergisi, 1(2), 108-118.

Yılmaz, E. (2014). Politik pazarlama ve politik pazarlama uygulamalarina yönelik ĕgilimler: Üniversite ögrencileri üzerine bir uygulama, Yayınlanmış Yüksek Lisans Tezi, Niğde Üniversitesi.

YSK. (2018). Seçim Sonuçlarl Bilgisi, Yüksek Seçim Kurulu. https://sonuc.ysk.gov.tr/sorgu (10.11.2019).

Yükselen, C. (2001), Pazarlama Araştırmaları (5. bs.). Detay Yayıncılık. 